\title{
The Role and Status of the Attorney in the Regulation of International Criminal Court in Light of the International Documents
}

\author{
Dr. Babak Pourghahramani \\ Department of Law, college of Humanities ,Maragheh Branch ,Islamic Azad University, Maragheh, Iran \\ Email: pourghahramani@iau-maragheh.ac.ir
}

\section{Doi:10.5901/mjss.2015.v6n6s4p410}

\begin{abstract}
One of the basic and fundamental rights of persons who are under investigation, prosecution and trial to ensure the fairness of the trial is the right of access to counseling and legal assistance as well as having the attorney that should be provided from the beginning of the penal process. This right has been clearly asserted in the international documents and regulations. The observance of this right is necessary not only in the national courts but also in the international courts. One of the international courts is the international criminal court that has been established to address international crimes. The objectives to study Identify the role and position of the attorney in the international criminal court As one of the fundamental rights of the accused and suspects and to evaluate its regulation from the view point of international documents. This study is an applied research and in descriptive method. The required information was collected with documentation and Library. By studying the regulation of the international criminal court it becomes clear that the mentioned authority has differentiated between the suspected and the accused and in both cases, it recognizes the existence of the attorney as necessary. In line with this, it emphasizes the right of victims to have legal assistance. Therefore, with the general review of the court's regulation and the international documents it might be stated that despite the existence of shortcomings in the court's regulation, the mentioned regulations and rules are more progressive compared to the international documents.
\end{abstract}

Keywords: Attorney, International Criminal Court, Defendants' rights, fair trial.

\section{Introduction}

The statute of international criminal court (ICC) has predicted two stages for criminal procedures; in the first stage, the authorities investigate the possible hypotheses about the origin of the crime and perpetrators who are likely to be involved in the crime. In this process, the investigating authorities are required to search, investigate and interrogate the persons. In fact, at this stage the prosecutor has credible evidence that suggests he/she may have committed a crime. In this stage, the investigated person cannot be addressed as the "accused" rather as the "suspected". 1

However, when the competent authorities of investigation formally raise the attribution of the crime to the person and ask punishment for him, the conversion of situation and the change of position happen, that is, the position of the person changes from the "suspected" to the "accused"2.

Now given that two stages of prosecution and two positions have been predicted in the statute of the international criminal court ${ }^{3}$, the court's statute has attached some rights for each of these stages entitled as "the rights of persons during the investigations" and "rights of the accused" including the right to have an attorney and legal assistance ( Mir Mohammad Sadeghi, 2005: p. 212; Kittichaisaree, 2001: pp. 340-341) that has been formally recognized in the statute ... it means what the role of attorney is in both stages (that is along the research "before the "confirmation of charges" and

\footnotetext{
${ }^{1}$ Although the international criminal courts of the former Yugoslavia and Rwanda used the term "suspected", the international criminal court does not use the term "suspected", rather it uses the term "person" before the verification of the accusation.

${ }^{2}$ Articles 55 and 61 of the statute of international criminal court.

3 The international criminal court or ICC is the first permanent international court established to address the international crimes. The statute of this court was approved on June 17, 1998 in Rome by the representatives of 120 countries and after the ratification of 60 countries it was entered into force on July 1, 2002. About 100 countries are members of court's statute and 139 countries have signed this statute. This permanent international court is located in the city of Hague. The international criminal court should not be confused with the international court of justice. The international court of justice is at the set of United Nations and addresses the government complaints against other governments, while the international criminal court prosecutes the real entities. The international criminal court has four main elements: presidency, prosecutorial, judicial branches and secretariat. The judges of court are 18 persons who specialized in the field of international law or criminal law. The consideration is done in two preliminary and revision stages. The judges of the international criminal court, in 2009, elected the judge Sang-Hyun Sung from the South Korea as the president of this court.
} 
trial procedure "after the confirmation of charges")? And what is the position of attorney in the international criminal court? And what terms and conditions have been predicted for the attorney in the regulation of the court? The present article addresses these in the light of international documents.

\section{The Role of Attorney in the Stage Before the Confirmation of Accusation}

Before the study of the lemma it should be noted that in the charters and trial rules of the international military courts ${ }^{4}$ there was not any effective guarantees for the rights of persons in the preliminary stage. The defective provisions of these charters didn't clearly specify any right to the persons in the research stage and the research stage was outside of its scope and even in the trial stage the support level was also at the lowest one and was criticized for unfair enforcement of rules (Fazaeli, 2011, p.364).

In the statute of international criminal court, article 55, clause (f) and (I) addresses the rights of persons and supports it in the research stage ${ }^{5}$, that is, the beginning of the criminal procedure, including the right to have the attorney as one of the rights and main guarantees of the fair trial. The role of attorney has been addressed in the first principle of the fundamental principles to verify this issue 6 "all people have right to benefit from the assistance of their selected attorney in order to protect and obtain their rights and to defend themselves in all stages of the criminal trial". Moreover, the resolution of the $15^{\text {th }}$ International Congress on Criminal Law (September, 10th, 1994) has predicted the right of access to the attorney from the first stages of forming the document (Khazani, 1997, p.472). In the review of the conventions on civil and political rights (1966) and the American conventions of human rights (1978), the African charter of human rights (1981), the European conventions on the protection of human rights and political freedom (1950), it is noticed that the right of having attorney or legal consultant in the stages before the trial has not been mentioned (Ziae Far, 2008, p.421) and perhaps the reason is that the above-mentioned documents, unlike the court's status, have not differentiated between suspected and accused person and they recognize the official beginning of the preliminary research only when the person is formally identified as the accused.

It is assumed that the under-investigation persons should have the rights prescribed for the accused that are applicable for their situation, firstly because it is not reasonable that the person who is not accused has the fewer rights than that of accused. In other words, it is not justifiable that the people's rights before being accused be fewer than their rights after being accused. Secondly, obviously each accused person is first a suspected one and it is his situation that changes him as an accused. Thus, it can be claimed that if a person has a special right when he is accused, how such a right can be allowed to be violated before having special protection. So, its initial reversal can result to the unprofitability of the next protection (Fazaeli, 2011, pp. 367-368).

However, it should be noted that when it is not believed that a person has committed one of the crimes falling under the jurisdiction of the court, the existence of attorney is canceled. But it is after this stage that the attorney finds a role. Based on the article 55 of the statute of international criminal court the person (suspected) has right to both choose an attorney and benefit from the free services of the attorney.

In this regard, the assembly of the states that are members of the court at its sixth meeting in 2007 recommended to the states to provide the possibility of the presence of attorneys of the accused persons in the court in order to guarantee their rights to defend themselves against the court (Delkhosh, 2012, p.367).

\subsection{The selective attorney}

The article 55 of the statute of the international criminal court (clause $f$ "2) related to the rights of persons along the investigations states that "if someone has committed one of the crimes falling under the jurisdiction of the court and is on the verge of interrogation whether by the prosecutor or national authorities, he/she has some rights to be aware of them before interrogation including: a)... b)... c)... To have legal assistance of the his/her selective attorney..." and according to the principle 20 of the trial regulation the head of the court's secretariat will do the necessary protections about the choosing of the attorney according to the principle 20 of the trial's rules and court's evidence. Also, according to the principle 112 of the above-mentioned rules, the person under interrogation can privately consult with his/her attorney and in the case of the refusal of having attorney it should be recorded in the written form.

\footnotetext{
${ }^{4}$ Like the military court of Tokyo

${ }^{5}$ Clause 1 of article 55 of statutes

${ }^{6}$ The basic principles on the role of attorney were accepted in the 8th Congress of United Nations on the prevention of the crime and the behavior with defendants that was held in Havan, Cuba, from the august 27 to September 7, 1990.
} 
This right has been clearly stated in the international committee for human rights that "all persons who are arrested must immediately have access to an attorney "and the principle 17 of the basic principles about the role of the lawyer emphasizes the right to be informed about the right to have the legal assistance.

Therefore, the right to choose the attorney starts when a person is arrested for the first time (whether he/she is accused or not) and if someone cannot have his/her selective attorney because of financial inability, then the relevant authorities will determine a free attorney for him/her if "interests of justice" make it possible.

But the question that is raised here and is noteworthy is "when the person is not interrogated, does the attorney has the right to be involved or not?! In other words, in this stage (prior to the approval of the charges) when the lawyer will have the right to intervene? From the statute of the court (article 55) it is assumed that lawyer can interference in the case when the person is subjected to be interrogated, but this perception is not true because it seems that the judicial authorities that are involved to provide the evidence, especially when the suspected person has been arrested, then the attorney can attend in the case without deferment.

\subsection{The public defender (attorney)}

The preliminary interrogation stage is not solely limited to the selective attorney; rather, this right has been predicted to the accused to have the free attorney if he/she does not have the financial ability to pay for the lawyer. But this right has faced with a limitation that is required to the interests of justice ${ }^{7}$ (clause I of the article 55 of the statute). The third principle of the basic principles obliges the governments to provide the necessary financial and other resources to offer the counseling services to the poor people. Although other related international documents have pointed to the public defender, but they are more related to the accused persons rather to the suspected.

As with the limitation on the "interests of justice", it has been contended that the importance of crime and the severity of related potential penalty and the complexity of issues raised in each case are the main criteria. However, this uncertainty that crimes have mainly severe penalties in the court's jurisdiction and this provision is meaningless. The European court of human right has suggested that the criterion "demand of justice" for determining the free attorney appears when an expert is required to take appropriate defense (Ghorbani, 2012, p. 232).

\section{The Role of Attorney in the Trial Proceeding (After the Confirmation of Charges)}

According to article 67 of the statute of the international criminal court (part 4 of clause 1), the accused can either defend himself or benefits from the attorney and to be informed about this right. The right to freely exchange ideas with the attorney who is appointed by the accused has been expressed in part 2 of clause 1 . Furthermore, according to trial principles and court's evidence, at any time after being arrested it is possible for the accused to ask and determine the attorney (clause 2 of principle 117). This right has been guaranteed in several international documents and even some of those account it necessary to inform the accused from this right including in article 14 (row "b" of clause 3) of the International Civil and Political Covenant, the European Convention of Human Right (row "f" of clause 3), article 8 (row "l" of clause 1) of American Convention on Human Right (R.K. Omidi, 2001, p. 21).

The first principle of basic principles on the role of attorneys states: "all people have right to benefit from the assistance of their selected attorney to protect and qualify their rights and to defend themselves in all stages of criminal proceeding. It is obvious that this right gives the possibility of an effective defense to the accused, while it strengthens the fairness of the trial and improves the public confidence to the criminal justice system. Although, the accused had the right to choose an attorney, he/she can refuse this right.

Now, in addition to the fact that the accused has the right to choose the attorney, and if he/she cannot afford, an attorney should be selected for him/her, provided that the justice allows it, the international documents of human right and international regulation all guarantee the right to have the free attorney for the accused. The part "l" of the clause 1 of article 67 from the statute of international criminal court ordains that "... if the accused has not the attorney or jurisconsult, then he/she has right to benefit from the assistance of jurisconsult who is provided by the court, if necessary and in regard to the administration of justice, even he/she to be unable to pay the related costs". Therefore, it is seen that this right has been accepted in the international criminal court and may be one of its reasons is that crimes and punishments as well as the trial regulation of the international criminal court have particular complexities and precision, so that the presence of one lawyer who is specialist in this area is necessary beside the accused (R.K. Saber, 2010, p.246).

7. In the convention of the civil and political rights (clause I of the clause 3 of article 14) and the European convention of the human rights (row of the clause 3 of article 6) this limitation and condition has been mentioned. 
It should be pointed out that with regard to the right of access to the attorney and legal assistance in the absence of selective attorney, in the international documents and human rights and also in the statute of court this criterion has always been mentioned that if the "interests of justice" make it possible, the attorney should be selected for the accused, but this criterion has not been expressed in none of the above-mentioned documents and it is ambiguous (Ibid, p. 247).

The article 67 of the statute of international criminal court, without providing any definition, mentions the use of assisting attorney of the court as "the inability of the defendant to pay for honorarium" and "to be interests of justice". The trial regulation of court and evidence of court have also paid attention to the conditions and the way to apply this right in items $8,20^{8}, 21^{9}$ and $22^{10}$.

\section{The Guarantee to Execute the Lack of Attorney in the International Criminal Court}

As we discussed, having the selective attorney and the right of being informed about it, and also determining a public defender in the case of financial inability have been proposed as the basic rights of persons in the regulations of the criminal court. The question that arises here is what executive guarantees have been predicted for the failure to observe this right by the court? Suppose that the person has not been informed about the right to have the attorney or he/she is unable to pay for the attorney and the public defender is not selected for him/her, what executive guarantee has been predicted for this basic right? Two kinds of executive guarantee, civil and political, have been predicted for states. Therefore, according to the article 41 of the European convention on the protection of human rights and fundamental freedoms of human (2004 AD), the articles 63 and 25 of the American convention on the human rights (1978 AD) and articles 24 and 25 of the African charter on human and people's rights (1982 AD), if the governments violate this right, the judicial entities of the region can condemn them to pay for fair compensation. In the political dimension, the global transnational criminal policy makers have also considered the political executive guarantee to protect the mentioned right. Therefore, the supportive monitoring entities according to a number of international documents including the international convention of political and civil rights will regulate and issue the declarations, resolutions and materials like that if they receive the report on the violation of the civil rights by the governments. Such response along with the stimulation of the judgment of the transnational public opinion towards the governments forces them to the accurate and strict execution of this right (Niazpour, 20081386, pp. 105-106). But, there is a problem that the guarantee of above-mentioned executions

\footnotetext{
8. The principle 20 of the trial principles and evidence of the court: 1- (c) Assist the arrested persons, persons to whom article 55, paragraph 2, applies and the accused in obtaining legal advice and the assistance of legal counsel; (d) Advise the Prosecutor and the Chambers, as necessary, on relevant defense-related issues; (e) Provide the defense with such facilities as may be necessary for the direct performance of the duty of the defense; (f) Facilitate the dissemination of information and case law of the Court to defense counsel and, as appropriate, cooperate with national defense and bar associations or any independent representative body of counsel and legal associations referred to in sub-rule 3 to promote the specialization and training of lawyers in the law of the Statute and the Rules. 2. The Registrar shall carry out the functions stipulated in sub-rule 1, including the financial administration of the Registry, in such a manner as to ensure the professional independence of defense counsel. 3. For purposes such as the management of legal assistance in accordance with rule 21 and the development of a Code of Professional Conduct in accordance with rule 8, the Registrar shall consult, as appropriate, with any independent representative body of counsel or legal associations, including any such body the establishment of which may be facilitated by the Assembly of States Parties.

9. Assignment of legal assistance; 1. Subject to article 55, paragraph 2 (c), and article 67, paragraph 1 (d), criteria and procedures for assignment of legal assistance shall be established in the Regulations, based on a proposal by the Registrar, following consultations with any independent representative body of counsel or legal associations, as referred to in rule 20, sub-rule 3; 2. The Registrar shall create and maintain a list of counsel who meet the criteria set forth in rule 22 and the Regulations. The person shall freely choose his or her counsel from this list or other counsel who meets the required criteria and is willing to be included in the list; 3. A person may seek from the Presidency a review of a decision to refuse a request for assignment of counsel. The decision of the Presidency shall be final. If a request is refused, a further request may be made by a person to the Registrar, upon showing a change in circumstances; 4 . A person choosing to represent himself or herself shall so notify the Registrar in writing at the first opportunity; 5 . Where a person claims to have insufficient means to pay for legal assistance and this is subsequently found not to be so, the Chamber dealing with the case at that time may make an order of contribution to recover the cost of providing counsel.

10. Appointment and qualifications of Counsel for the defense; 1. A counsel for the defense shall have established competence in international or criminal law and procedure, as well as the necessary relevant experience, whether as judge, prosecutor, advocate or in other similar capacity, in criminal proceedings. A counsel for the defense shall have an excellent knowledge of and be fluent in at least one of the working languages of the Court. Counsel for the defense may be assisted by other persons, including professors of law, with relevant expertise; 2. Counsel for the defense engaged by a person exercising his or her right under the Statute to retain legal counsel of his or her choosing shall file a power of attorney with the Registrar at the earliest opportunity; 3. In the performance of their duties, Counsel for the defense shall be subject to the Statute, the Rules, the Regulations, the Code of Professional Conduct for Counsel adopted in accordance with rule 8 and any other document adopted by the Court that may be relevant to the performance of their duties.
} 
has been predicted for governments, but it is not applicable for international criminal courts that the governments are its members and considering the regulation of the international criminal court it is clear that there is not any particular regulation in this area and it is silent from this aspect, while the violation of such basic right should not be remained without the executing guarantee.

\section{The Place of Attorney in the Regulation of the International Criminal Court}

While carrying out their duties, the lawyers should follow the relevant provisions in the statutes, trial regulation and the court's evidence and other relevant principles and regulations including rules of arrest, the professional codes of behavior and ethics and applicable regulations in the guide of determination of barrister. However, a special status and particular conditions have been predicted for the attorney in the court's regulation. Some of them are described below.

\subsection{Ensuring the attorney's autonomy}

Since the right of defense is one of the most important rights and has special sanctity, the requirement to appropriately apply it hinges on the accused access to the assistance of attorney in all stages of the investigation as the defendant who is in the trial or arresting procedure, on the one hand, the presumption of innocence is true about him and on the other hand, he might not be aware of his legal rights to apply them in order to defend himself. Additionally, it is possible that the incorrect and non-standard ways are used in the process of initial investigation for the admission of the charge by the court and security authorities and the rights of defendant to be violated. For this reason, most countries have stipulated the right of accused to have the services and defense of attorney in all stages of investigation and also the duty to declare and explain these rights to the accused from the beginning to the end of the investigation by the authorities in their regulations and even they don't recognize the trial without the presence of the attorney as the legal trial. The fulfillment of such important task requires the security of the attorney in addition to his/her autonomy from the judiciary system. This principle has been explicitly predicted in the clause (b) of the article 67 of the statutes and the clause 2 of the principle 20 of the trial regulation and court's evidence with this context that the professional autonomy of the barristers should be ensured. The court itself has done several helps through the secretariat according to the principle 20 of the trial regulation including attracting the cooperation of international governments and institutions for ensuring the security of the barristers and in this regard, the barristers' team benefits from the advantages and securities resulting from the securities and advantages agreement. It should be noted that the court has completely relied on the cooperation of governments in providing the observation of the securities and benefits of barristers and the attorneys like the court's members will have the government's assistance and support. These assistances will be offered by both the regional offices of the court (located in the keeping place of accused (s)) and the offices of the national organization and the governments.

Although, the above-mentioned principle has not been explicitly mentioned in the international documents, it can be inferred from their contexts. According to the $11^{\text {th }}$ article of the universal declaration on human rights, all necessary guarantees to defend from the accused should be provided. It is evident that the necessary guarantees are all guarantees and some cases that ensure the physical and mental freedom of the accused during the interrogation, trial and his/her legal rights from the beginning to end and the sentencing of the definitive verdict, so that he/she can enjoy from the recognized human rights in addition to the defense against the attributed charge (s) through existing facilities. On the other hand, the maximum of these guarantees is that the defendant benefits from the services of the attorney who can appropriately help the court in holding a fair trial because of having knowledge about the defendants' rights.

The article 14 of the covenant on the civil and political rights not only specifies the equality of individuals before the courts and necessity of the fair investigation in the independent and impartial court, but also enumerates some guarantees contained in the article 11 of the universal declaration of the human rights and in the sections "a", "b" and "c" of the clause 3 of that article it points to the right of the accused to be informed about the type of the charge and reasons for it, in the language that can be understood, giving facilities of contact with his/her selective attorney that is completed with the clause "d" that mentions the presence of the accused (s) and his/her attorney in the court and defense from charges by the accused or his/her attorney. The role of attorney is not so important in the article 14 in terms of his/her supportive aspect that it is necessary to declare the right of having the attorney to the accused and even if he/she cannot afford the honorarium of the attorney, the court will determine the attorney without any cost for him/her. The contents of this international document only is used to emphasize the importance of the existence of the attorney and his/her defense from the accused, because when the right to have the attorney is one of the obligations of the accused's trial and it is so important that it should be initially declared to him/her so that he/she introduces his/her attorney to the court. Most importantly, if the interests of justice know it as appropriate, it will directly determine an attorney to the accused; he/she 
also can freely benefit from the services of the attorney if he/she is not able to pay the honorarium, so no place remains for another conclusion from these notes and emphases.

Therefore, where the defense and the assistance of the attorney with the accused have such importance, the existence of independence and security for the attorney is obvious and inevitable. Because it is not rational and possible that an element to be so important in the trial that the covenant of his/her presence to be recognized as a necessity, even to be paid by the court and that element (attorney) has not the necessary independency and guarantees associated with the defense.

In the eighth United Nations Congress on the prevention of the crime and treatment with the accused (s) that has raised the basic principles of the attorneys' role, in the article 16 it enumerates the necessary securities and supplies required to perform the duties of the attorney including doing these duties without any threat, hindrance, harassment or improper interference, travel within and outside the country in order to counsel with the clients, without any official, economic prosecution and punishment and other punishments. These are the issues that today's the necessity of their presence has been strongly felt, because if the attorneys are faced with the threat and harassment in connection with defense from a case, or some obstacles may be created for them that interrupt the freedom to defend the people's rights, he/she cannot provide a comprehensive and proper defense. Because the attorney is a human being and cannot fully concentrate on the defense in unsafe and disturbed conditions, so he/she will lose the mental tranquility necessary to offer the proper defense that its direct result is the violation of the accused's rights that sometimes is irrecoverable. In this regard, article 17 also considers some cases in which the security of the attorneys have been violated so that its result is the failure to perform their duties (this case is abundant in the attorney profession who are threaten by the person(s) for their withdrawal from the case or continue it in a way that is desirable for the threatener). Therefore, in this case, according to the article 17 of the declaration, the authorities have the duty to properly protect from the attorney. The article 20 also mentions the penal and civil security of the attorneys related to the petitions and bills delivered to the court and other responsible authorities for defense and objections. The inclusion area of this security involves the oral statements and even the presence of the attorney, of course, these cases should be bound to the goodwill of the attorney that with accepting the principle that the defense right is one of the basic rights of each defendant; naturally no malicious intent cannot be thought for the attorney in the position of defense. The articles 21 and 22 have noted the possibility of the attorney to access to the available records, data and documents as well as the confidentiality of the attorneys' consultations and communications with the clients in order to provide the proper legal services to them.

The rights and freedom such as freedom of speech, professional associations without any limitation, fair and rapid investigation of any charges and complaints against the attorneys according to the particular trial regulation, and also dealing with discipline cases by specific committees and independent authorities have been also predicted in articles 23 to 28 that all indicate the necessity of independency and special security of the attorneys who are responsible of the risky task of defending in the courts and if these principles are not met or partially applied, the defense and consequently the trial won't properly achieved and it is not accepted by the human society.

In the preface of the basic principles of independency of the attorney profession approved by the international association of lawyers and the statute of the union of lawyers it has been stated that: "independency of the attorney profession involves the protection and promotion of the human rights, establishing and maintaining the governance of the law in the society and it is considered as one of the basics of the fair trial; so the states are required to respect and consider these basic and fundamental principles and put them into practice".

The article 17 of the above motioned principles also provides: "the associations of the court's attorneys should be independent and their basics, rules and board of directors should be freely selected by theirs members (the court's attorneys) without the interference of any person and external entity". The mentioned cases imply the need for the independency of the attorney profession and the security of the court's attorneys. The statutes of the association of the attorney approved in the July $8^{\text {th }}, 1927$ in the article 20 also states "the international association of lawyers expresses its universal nature with allying the associations of lawyers and attorneys and their professional entities in the worldwide and considering and respecting to the variety of the legal systems and existing cultures". In the article 3 of the statute, the improvement of the fundamental basics of the attorney's profession in the worldwide, especially the principle of independency and freedom of attorneys towards the interests of all people acting in the judicial system has been noted as one of the association's goals.

\subsection{The confidentiality of the communications and conversations of the attorney with the client}

The barrister should be able to do the process of defense freely without any external pressure. The free and confidential communication of the accused with the selective attorney has been recognized as the essential right of the accused in 
the international criminal court. According to the article 20 (row "a" of the clause 1) of the court's statute, the protection from the secrecy in the mentioned way will be facilitated in the clause (b), paragraph 1 of the article 67 of the statute. The article 67 that is about the expression of the accused's right has stated that "the accused should have the enough time and facilities to prepare the defense and can freely and confidentially communicate with his/her selective attorney".

This principle has been emphasized in different international regulations and the court's statute is also inspired from it. According to the article 14 of the covenant on the civil and political rights (part "b" of clause 3), principles 8 and 28 of the basic principles of the attorneys' role, principle 18 of the set of principles on the protection from all persons under any form of detention and imprisonment, article 93 of the regulation of the prisons affairs, paragraph 2 of the clause 5 and the resolution on the right to have the fair trial of the African Commission of the human rights, the authorities should respect the confidentiality of the contacts and counseling between attorneys and their clients. One of the requirements on the observance of the mentioned right according to the international documents is that no audio eavesdropping or the censor of the oral or written contacts do not be applied and the authorities ensure that the attorneys can consult and offer the services in accordance with the professional standards (Ziaiefar, 2008, p. 425).

\subsection{Terms and conditions on the attorney}

As it was already discussed, the statute of the court has recognized the right to have the attorney for both the investigation stage and trial stage; and numerous international documents have also emphasized it. In this regard, the third discussion of the trial principles and the court's evidence has been specified to the barrister that according to it the attorneys who are chosen for the defendants should (R.K. Kousha, Taghipour, 2007, p. 27):

- Their competence should have been recognized in the international law or [international] criminal law and trial regulation and they should also have the necessary knowledge and experience as the judge, prosecutor, attorney or they should have other similar abilities in the criminal investigations. He/she should have the knowledge of and to be fluent in at least one working language on the court. Other persons like the professor in law with relevant expertise can assist the barrister in this matter.

- Every person who employs a barrister according to the statutes to benefit from his/her right and to have legal counsel, should declare the authorities of the attorney to the office manager as soon as possible.

- The barristers in carrying out their duties should act in line with the statutes, trial regulation, [court] regulation, set of regulations on the professional behavior for the [legal] counselor according to the article 8 [trial regulation] and every other documents approved by the court that are related to the execution of their duties.

Now it might be inferred that the specification of limits and authorities of the public defender and the reorganization of competences and regulation on his/her appointment will be the responsibility of the head of secretariat (administrative authority). Therefore, it appears that the predicted order is with the independency of the advocacy that is one of the requirements of a fair trial and an independent advocacy entity in the international criminal affairs, not the official authorities of the court, should be responsible of the recognition of the competences and son (Saber, 2010, p. 250).

According to the article 67 of the court's regulation approved in 2004,5,26, Criteria to be met by counsel include necessary relevant experience for counsel as described in rule 22 should be at least ten years and should not be convicted of as a serious criminal or disciplinary offence considered to be incompatible with the nature of the office of counsel before the Court.. The attainment and the control of the attorneys' criteria will be done by the head of the secretariat ${ }^{11}$ and the person who tries to be placed in the list of the court's attorney will be placed in the list of attorneys if the conditions of the article $69^{12}$ are met.

Moreover, according to the article 71 of the regulation, the person will be removed from the list of attorneys when he/she loses the necessary criteria or is prohibited from the advocacy in court by virtue of the disciplinary sentence, or is recognized as the criminal because of committing a crime against the justice as mentioned in article 70 of the statutes and/or to be permanently deprived from the advocacy according to the principle 171 of the trial regulation. Additionally, the person will be suspended from the list of the attorney when he/she being suspended in an investigation according to the rules on the professional behavior or temporarily being deprived from doing his/her duties for more than 30 days.

It should be noted that the regulation of the criminal court has recognized the standby attorney in the urgency and critical cases ${ }^{13}$.

\footnotetext{
11. Article 69 of the court's regulation

12. Required conditions, the certificated issued by the attorneys' association that the person is the member of it, the certificate issued by the related authorities or mentioning the criminal conviction, personal resume and ...

13. Article 73 of the regulation.
} 


\subsection{The commitment of attorney to the effective defense}

In numerous transnational documents and procedures it can be found that when we talk about the right of attorney it means the competent legal consultant, and also having the moral and professional qualifications and commitment to the serious defense from his/her client. Thus, in the international standards it has been highlighted that the countries should ensure that he/she is an effective legal consultant and representative for the client (Ziaeifar, previous, p.425). The principles 12 to 22 of the document on the basic principles of the attorneys' role in detail have expressed the attorney's duties towards his/her client and also the supervision that the governments should take its responsibility in order to ensure the execution of the attorneys' duties. Inter-American commission of human rights, in one case, has stated that since the attorney has failed to fulfill his commitments, then the right to enjoy from the attorney has been violated (Ghorbani, 2012, p. 231). According to the judicial procedure of the European court of the human rights, the judicial assistance is not nominal and virtual; rather, it should be effective and beneficial to the accused's status. This effect has three prestige: first, if the crime has the particular complexity the accused should benefit from the assistance of the experienced attorney; second, the statements of the attorney or the consultant should not be limited only to the oral expression of the defense, rather the attorney, if necessary, should be allowed to challenge the witnesses on behalf of the accused and third, the attorney should have the proper time to offer the defense (Ghorbani, 2012, p. 231).

In the statute of the international criminal court, such an issue has not been predicted, but it has been predicted in the trial principles and the court's evidence. According to the principle 20 of the trial principles and the court's evidence, according to the clause 1 , article 43 [statutes], the office manager organizes the office workers in a way that they improve the rights of defense related to the principle of the fair trial as defined in the statutes. To this end, the head of secretariat should support and assist all barristers who are present in the court and provide the information for them and support the professional detectives for the efficient behavior and the effective defense. Although, the executive guarantee has not predicted for the efficient and effective defense, it can be inferred from the regulation that if the attorneys lose the necessary criteria, then they will be removed from the list of attorneys.

\section{The Victims ${ }^{14}$ ' Right to have the Attorney}

Most of documents that have been approved about the fair trial advocate the rights of the accused including having the attorney and there is no discussion about the role of attorney in protecting the victims' rights ${ }^{1}$. While the fair trial is not confined to the accused rather it is effective to the victim, too. The statute of Rome for the first time in the history of the international criminal court made it possible to give the right of having the attorney to the victims in order to participate in taking their rights. According to article 68 (3) of the Rome's statute "where the personal interests of victims are violated, the court will allow their ideas and concerns to be presented and to be investigated in different stages of the trial that the court will be recognized as appropriate and in a way that is not in contrast with the defendant's right as well as a fair and impartial trial and the mentioned ideas and concerns can be presented by the legal representatives of the victims, if the court recognizes it as appropriate according to the trial principles and the evidence". Given this, the Rome's statute has caused a major revolution in the victims' rights and has allowed the involvement of the victim in the trial.

What is notable here is that with regard to the point that the international crimes usually involve numerous victims and survivors, how this issue is applicable in practice? Noting this fact that the court, according to the article 68(3), should make a balance between its goals, fair trial and the right of victims to participate in the trial, a large number of victims of crimes should not undermine the fair trial. The trial regulation and the court's evidence establish this balance in two ways:

First, by limiting the number of the victims' representatives

Second, by stating some conditions for the entrance of representatives to the court.

In the first limitation, the victim who wishes to provide the personal representative should submit a written request to the investigating board of the court. This board tries to obtain the ideas of the prosecutor and the defendant before making a decision. In the cases where there are many victims, in order to guarantee a useful trial it is possible to request from the victims or a group of them to choose their common legal representative(s) (principle 90 (3)). If the victims cannot

\footnotetext{
14. From the view of the statute of the international criminal court and the regulation of evidence and trial of the court, the victims are real persons that have been damaged as the result of committing the crime which is in the competence of the international criminal court. The definition from the victim of the crime can also include the legal entities (persons) that have suffered from the direct damage to their property which have been specified to the religious, training, artistic issues or scientific and charitable purposes and to the historical monuments of hospitals and other places and the materials related to the humanitarian purposes. The victims or their the legal representatives can take part in the trials in order to express their comments and concerns.
} 
choose a common legal representative, then the tendentious board asks the office manager to choose one or more common legal representatives. According to principle 90(3) the board and office of the court do all necessary measures to ensure that the common legal representatives have become aware of distinct and obvious interests of victims and to prevent the contrast between the interests (principle 90(4)).

As to the second limitation, the principles of the court have provided some provisions and limitations for the entrance of the legal representatives in order to provide the useful trial. The principles of the court give the right of participation in the trial to the victims or their representative without considering the pre-conditions. The principle 89 (1) (3)) obligates the victims or persons who act on behalf of them to submit their written petition about the participation in the trial to the court. The court makes it possible to the accused and the prosecutor to comment about that petition and then it specifies a way according to which the participation is recognized as appropriate. The principle 91(2) allows to the victim to present and involve in the trial, unless the court points to the principles that their involvement must be in the written bills and limited to the comments. However, according to the principle 91(3) some limitations have been on the authorities of the legal representatives of victims in questioning the witnesses, experts and accused, so that they should request the above mentioned items from the court and the court according to the defendant's rights, the interest of witnesses and the necessity of a fair trial will decide in line with the article 68 of the statute. Moreover, according to the principle 91(4) it has been generally allowed to the representative of the victim to ask some questions about the redress, though the court can prevent such action in terms of its own discretion.

\section{Conclusions}

The right of being informed about having an attorney in the initial stages of the interrogation has been emphasized as one of the terms of the fair trial in the international documents and regulations. The international criminal court inspired by the above documents has also recognized this right, though the regulations of the above documents are accused-oriented rather suspected-oriented. Additionally, if he is unable to pay for the honorarium, an attorney must be determined for him. This right not only has been specified to the suspected and accused of the crime, but also to the victims of the crime too. The statute, the trial principles and the court's evidence have the most advanced texts compared to the international documents in this area, though no particular executive guarantee has been predicted for the violation of such a right. Moreover, the attorney has a special place in the regulations of the international criminal court and necessary supports has been applied in this regard including the authority of the attorney, confidentiality of the conversations and correspondence with the accused, the way and conditions required to select them and commitment of the attorney to the effective defense. Nonetheless, some ambiguities or shortcomings are seen in some regulations of the court that is better to be removed including the lack of the executive guarantee, the lack of attorney at the court, the ambiguity of the provision "interests of justice" in the public defender, the authority who defines the attorney in the trial by countries under the order of the court, submitting the clarifying the attorney's competence to an official entity.

\section{References}

Omidi, J.(2001).The human right in the criminal claims based on the international and regional documents. Journal of the law and politic science college, 49,5-33

Khazani, M., Ardabili.M.A.,\&Najafie Abrandabadi. A.H.,(1997), The $15^{\text {th }}$ international congress on criminal law, Journal of the law research, 16 \& 17,220-245

Delkhosh, A.(2012). Countering with the international crimes.(1th ed). Tehran, Jungal.

kittichaisaree, K (2001), The international criminal law.(1th ed).USA, Oxford University Press.

Saber, M.(2010). The trial code of the international criminal court.(1th ed).Tehran, Dadgostar.

Ziaiefar, M. H. (2008). The right to have the attorney or legal consultant in the preliminary investigation stage: with emphasis on the procedure of the European court of the human rights, the fundamental rights Journal. 8.415-440

Fazaeli, M. (2011). The fair trial of the international penal trials. (2th ed). Tehran, Shahre Danesh.

Ghorbani, A. (2012). The fair trial in the procedure of the European court of the human rights.(1th ed). Tehran, Hoghughe Emrooz.

Kousha, J.,\& Taghipour, A. (2007). The right of access to the attorney in the international criminal courts of Yugoslavia, Rwanda and international criminal court from the viewpoint of the human right, the journal of Nameye Mofid.55.19-34

Mir Mohamad Sadeghie, H.(2005). International criminal court.(1th ed). Tehran, Dadgostar.

Niazpour, A. H,. (2008). The right of accused (s) in terms of having the attorney in the criminal procedure; A manifestation of civil rights, the law journal. 58.93-118. 